\title{
Pengaruh Variabel Makroekonomi Terhadap Indeks Harga Saham Gabungan (Studi pada Indeks Harga Saham Gabungan di Bursa Efek Indonesia Periode 2014-2018)
}

\author{
Rina R. Mamahit \\ Tinneke M. Tumbel \\ Joanne V. Mangindaan \\ Jurusan Ilmu Administrasi Program Studi Administrasi Bisnis \\ Fakultas Ilmu Sosial dan Politik Universitas Sam Ratulangi Manado \\ Email: rinamamahit48@gmail.com
}

\begin{abstract}
This research aims to determine whether the macroeconomic variables i.e., the exchange rate, inflation and BI rate simultaneously and partially influence Indonesia Composite Index at The Indonesia Stock Exchange (IDX). The approach in this study is a quantitative method, using multiple linear regression analysis. The data used are time series data from January 2014 until December 2018. The result indicates that exchange rates, inflation and BI together have a significant impact to Indonesia Composite Index. Individually, only the BI rate variable has a significant effect and has a negative effect to Indonesia Composite Index. The exchange rate and inflation had no significant effect to Indonesia Composite Index.
\end{abstract}

Keywords: Macroeconomic Variables, Indonesia Composite Index.

\section{Pendahuluan}

Pasar modal berperan penting dalam menunjang perekonomian Indonesia. Sebagai wahana yang mempertemukan dua kepentingan yaitu pihak yang memerukan dana (emiten) dan pihak yang memiliki kelebihan dana (investor), pasar modal menjadi sarana investasi bagi masyarakat luas serta sumber pendanaan jangka panjang bagi perusahaan. Saham (stock) merupakan salah satu instrumen pasar keuangan yang paling populer. Menerbitkan saham merupakan salah satu pilihan perusahaan ketika memutuskan untuk pendanaan perusahaan. Pada sisi yang lain, saham merupakan instrument investasi yang banyak dipilih para investor karena saham mampu memberikan tingkat keuntungan yang menarik (www.idx.co.id).

Di pasar sekunder atau dalam aktivitas perdagangan saham sehari-hari, harga-harga saham mengalami fluktuasi baik berupa kenaikan maupun penurunan. Pembentukan harga saham terbentuk oleh supply dan demand atas saham tersebut. Supply dan demand tersebut terjadi karena adanya banyak faktor, baik yang sifatnya spesifik atas saham tersebut (kinerja perusahaan dan industri dimana perusahaan tersebut bergerak) maupun faktor yang sifatnya makro seperti tingkat suku bunga, inflasi, nilai tukar dan faktor-faktor non ekonomi seperti kondisi sosial dan politik, dan faktor lainnya (www.idx.co.id). 
Penelitian yang dilakukan oleh Kumalasari (2016) menunjukkan bahwa secara parsial variabel nilai tukar berpengaruh positif signifikan terhadap variabel indeks harga saham gabungan. Hasil yang berbeda ditunjukkan dari penelitian yang dilakukan oleh Jayanti (2014) dimana nilai tukar Rupiah secara parsial mempunyai pengaruh negatif dan signifikan terhadap indeks harga saham gabungan.

Dari hasil penelitian yang dilakukan oleh Jayanti (2014) tingkat inflasi secara parsial mempunyai pengaruh positif dan tidak signifikan terhadap IHSG. Sedangkan penelitian yang dilakukan Sunardi dan Ula (2017) menunjukkan bahwa inflasi berpengaruh negatif dan signifikan terhadap indeks harga saham gabungan (IHSG) yang tercatat di Bursa Efek Indonesia (BEI).

Penelitian yang dilakukan Kumalasari (2016) menunjukkan bahwa BI rate berpengaruh negatif signifikan terhadap IHSG. Hasil penelitian tersebut didukung pula oleh penelitian yang dilakukan Taufiq dan Kefi (2015) dimana BI rate berpengaruh negatif dan signifikan terhadap IHSG.

Dari berbagai hasil penelitian di atas, masih terdapat celah (gap) teori yang bisa dibuktikan secara empiris tentang hubungan antara variabel kurs, inflasi, BI Rate dan Indeks Harga Saham Gabungan untuk membuktikan sifat hubungan antar variabelvariabel tersebut apakah parsial atau bersamasama atau keduanya serta apakah hubungan tersebut positif atau negatif. Untuk itu peneliti tertarik untuk menganalisis pengaruh variabel- variabel makroekonomi tersebut terhadap Indeks Harga Saham Gabungan (IHSG) di Bursa Efek Indonesia.

\section{Pasar Modal}

Pasar modal adalah pasar dari berbagai instrument keuangan (sekuritas) jangka panjang yang dapat diperjualbelikan, baik dalam bentuk hutang (obligasi) maupun modal sendiri (saham) yang diterbitkan pemerintah dan perusahaan swasta (Suad Husnan, 1994). UU No. 8 tahun 1995 tentang pasar modal mendefinisikan pasar modal sebagai kegiatan yang bersangkutan dengan penawaran umum dan perdagangan efek, perusahaan publik yang berkaitan dengan efek yang diterbitkannya, serta lembaga dan profesi yang berkaitan dengan efek.

\section{Indeks Harga Saham Gabungan}

Indeks harga saham adalah suatu indikator yang menunjukkan pergerakan harga saham. Indeks berfungsi sebagai indikator tren pasar, artinya pergerakan indeks menggambarkan kondisi pasar pada suatu saat, apakah pasar sedang aktif atau lesu (Martalena dan Maya, 2011). Abdul (2006: 12), menyatakan bahwa Indeks Harga Saham merupakan ringkasan dari pengaruh simultan dan kompleks dari berbagai macam variabel yang berpengaruh, terutama tentang kejadian-kejadian ekonomi. Indeks Harga Saham Gabungan atau IHSG merupakan indeks yang menunjukkan pergerakan harga saham secara umum yang tercatat di bursa efek yang menjadi acuan tentang perkembangan kegiatan di pasar modal. IHSG di tentukan dengan mengunakan 
seluruh saham yang tercatat di Bursa Efek Indonesia, dimana digunakan tanggal 10 Agustus 1982 sebagai nilai dasar IHSG.

\section{Nilai Tukar (Kurs)}

Bank Indonesia menyatakan bahwa nilai tukar suatu mata uang didefinisikan sebagai harga relative dari suatu mata uang terhadap mata uang lainnya. Dalam menentukan mata uang asing dikenal tiga sistem yang diterapkan di semua negara di dunia, yaitu sistem kurs tetap (fixed change rates), kurs mengambang terkendali (managed floating exchange rates) dan kurs mengambang bebas (free floating exchange rates) (Bank Indonesia, 2003:69).

\section{Inflasi}

Inflasi adalah kecenderungan dari harga-harga untuk meningkat secara umum dan terus menerus. Kenaikan harga dari satu atau dua barang saja tidak dapat disebut inflasi kecuali bila kenaikan itu meluas (atau menyebabkan kenaikan) kepada barang lainnya. (Bank Indonesia). Karhi dan Winardi (1997:217) mengemukakan bahwa inflasi merupakan sebuah fenomena yang dilalami oleh sejumlah besar negara-negara di dunia.

\section{BI Rate}

Menurut Bank Indonesia, BI rate adalah suku bunga kebijakan yang mencerminkan sikap atau stance kebijakan moneter yang ditetapkan oleh Bank Indonesia dan diumumkan kepada publik. BI rate diumumkan oleh Dewan Gubernur Bank Indonesia setiap Rapat Dewan Gubernur bulanan dan diimplementasikan pada operasi moneter yang dilakukan Bank
Indonesia melalui pengelolaan likuiditas (liquidity management) di pasar uang untuk mencapai sasaran operasional kebijakan.

\section{Kerangka Pemikiran}

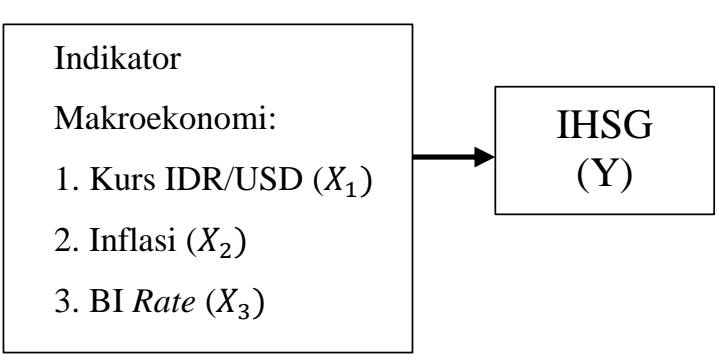

Gambar 2.1

Kerangka Pemikiran

\section{Hipotesis}

Berdasarkan perumusan masalah dan kajian empiris yang telah dilakukan sebelumnya, maka hipotesis yang diajukan dalam penelitian ini adalah:

$\mathrm{H}_{a 1}$ : Nilai tukar IDR/USD, inflasi dan suku bunga (BI rate) secara bersama-sama berpengaruh signifikan terhadap IHSG.

$\mathrm{H}_{a 2}$ : Kurs berpengaruh signifikan terhadap pergerakan IHSG.

$\mathrm{H}_{a 3}$ : Inflasi berpengaruh signifikan terhadap pergerakan IHSG.

$\mathrm{H}_{a 4}$ : BI rate berpengaruh signifikan terhadap pergerakan IHSG.

\section{Metode Penelitian}

Jenis data dalam penelitian ini adalah data kuantitatif dari Januari 2014 sampai dengan Desember 2018. Sumber data yang digunakan adalah data sekunder yang bersumber dari Bursa Efek Indonesia, Bank Indonesia dan Badan Pusat Statistik. 
Penelitian ini menganalisis pengaruh nilai tukar IDR/USD, inflasi dan tingkat suku bunga BI Rate terhadap IHSG. Untuk mengetahui pengaruh tersebut digunakan teknik analisis regresi linier berganda. Analisis regresi dalam penelitian ini menjadi alat untuk mengukur bagaimana pengaruh dari variabel independen terhadap variabel dependen. Tujuan dari analisis regresi adalah untuk memprediksi besarnya variabel dependen dengan menggunakan data variabel independen yang sudah diketahui besarnya (Santoso, 2000: 163).

Sebelumnya dilakukan pegujian persyaratan analisis (uji asumsi klasik) yakni normalitas, multikolinearitas, autokorelasi dan heteroskedastisitas. Setelah itu dilakukan uji signifikansi model, yakni dengan melakukan uji $F$, uji t, dan koefisiensi determinasi (R2). Uji $F$ dilakukan untuk mengetahui seberapa besar variabel independen maupun mempengaruhi variabel dependen secara simultan (bersama-sama). Uji $\mathrm{T}$ dilakukan untuk melihat sejauh mana pengaruh variabel independen terhadap variabel dependen secara parsial (individu). Selain itu uji koefisien determinasi (R2) ditujukan untuk melihat seberapa besar kemampuan variabel independen menjelaskan variabel dependen.

\section{Hasil Dan Pembahasan}

\section{Hasil Penelitian}

Berdasarkan uji determinasi, ditemukan bahwa sebesar $58,8 \%$ dari variabel dependen indeks harga saham gabungan dijelaskan oleh variabel independen kurs, inflasi dan BI rate.
Sisanya sebesar 41,2\% dijelaskan oleh variabel lain di luar yang digunakan dalam penelitian ini.

Pengaruh variabel makroekonomi terhadap IHSG dapat dilihat dari hasil uji $\mathrm{F}$ tabel dimana nilai $p$-value $0,000<0,05$, dan $F_{\text {hitung }} 29,078>$ dari $F_{\text {tabel }} 2,77$ yang menunjukkan bahwa secara simultan variabel makroekonomi yang diproksikan dalam variabel kurs, inflasi dan $\mathrm{BI}$ rate secara bersama-sama berpengaruh signifikan terhadap indeks harga saham gabungan di Bursa Efek Indonesia.

Berdasarkan uji $\mathrm{T}$, variabel kurs memiliki nilai $\mathrm{p}$-value $0,646>0,05$ dan $\mathrm{t}_{\text {hitung }}$ $0,462<t_{\text {tabel }} 2,00$, dengan demikian Ho diterima dan Ha ditolak. Hal ini menunjukkan bahwa secara parsial kurs tidak berpengaruh secara signifikan terhadap IHSG. Koefisien regresi kurs (X1) sebesar 0,031 menunjukkan besarnya pengaruh kurs terhadap IHSG. Dengan demikian, kurs memiliki korelasi yang positif namun tidak signifikan dengan IHSG.

Variabel inflasi memiliki p-value 0,827 $>0,05$ dan $t_{\text {hitung }}-0,22<-t_{\text {tabel }} 2,00$ dengan demikian Ho diterima dan Ha ditolak. Hal ini menunjukkan bahwa secara parsial inflasi tidak berpengaruh secara sigifikan terhadap IHSG. Berdasarkan analisis regresi linear berganda, koefisien regresi inflasi $\left(\mathrm{X}_{2}\right)$ sebesar $-9,918$ menunjukkan besarnya pengaruh tingkat inflasi terhadap IHSG.

Variabel BI rate memiliki p-value 0,000 $<0,05$ dan $t_{\text {hitung }}-5,959>\mathrm{t}_{\text {tabel }} 2,00$ dengan demikian Ha diterima dan Ho ditolak. Hal ini menunjukkan bahwa secara parsial BI rate 
berpengaruh secara negatif dan signifikan terhadap IHSG. Koefisien regresi BI Rate (X3) sebesar $-318,913$ menunjukkan besarnya pengaruh BI Rate terhadap IHSG.

\section{Pembahasan}

Sebesar 58,8\% dari variabel dependen indeks harga saham gabungan dijelaskan oleh variabel independen kurs, inflasi dan BI rate. Sisanya sebesar $41,2 \%$ dijelaskan oleh variabel lain di luar yang digunakan dalam penelitian ini. Variabel lain tersebut bisa berupa mikroekonomi perusahaan seperti pembagian deviden, perubahan strategi perusahaan, maupun indikator makroekonomi lain seperti PDB, jumlah uang beredar, suku bunga SBI serta informasi-informasi lain yang dapat digunakan oleh para investor untuk mengambil keputusan. Variabel lainnya bisa juga berupa pengaruh eksternal yaitu kondisi dan stabilitas ekonomi global.

Secara simultan variabel makroekonomi yang diproksikan dalam variabel kurs, inflasi dan BI rate secara bersama-sama berpengaruh signifikan terhadap indeks harga saham gabungan di Bursa Efek Indonesia. Keterkaitan ketiga variabel makroekonomi tersebut dengan IHSG juga dapat diamati secara langsung berdasarkan data historis selama tahun 2014-2018.

Sepanjang 2014, rupiah cenderung melemah hampir pada sepanjang tahun 2014, kecuali pada triwulan I 2014. Pelemahan ini merupakan respon kebijakan Bank Indonesia untuk mengarahkan inflasi agar tetap terkendali. Selain itu, untuk menyikapi kenaikan ekspektasi inflasi pascakebijakan kenaikan harga BBM bersubsidi dan peningkatan tekanan rupiah, Bank Indonesia menaikkan BI Rate. Terkendalinya inflasi IHK terlihat dari dinamika inflasi bulanan (monthto-month atau $\mathrm{mtm}$ ) pada triwulan I yang terus menurun dan bahkan lebih rendah dari historisnya pada triwulan II sampai dengan triwulan III. Terlepas dari berbagai faktor global maupun faktor kondisi ekonomi dan politik dalam negeri yang melanda di sepanjang tahun 2014, perkembangan pasar modal Indonesia secara keseluruhan masih menunjukkan kinerja dan pertumbuhan yang positif dimana IHSG mengalami tren kenaikan dan bergerak dengan volatilitas yang cukup terjaga.

Secara umum, rupiah berada dalam tren depresiasi selama tiga triwulan pertama 2015 dengan tekanan yang semakin meningkat pada triwulan III 2015. Namun pada triwulan IV 2015, rupiah memasuki fase stabilisasi seiring dengan menurunnya ketidakpastian di pasar keuangan global. Meski demikian, Inflasi Indeks Harga Konsumen (IHK) 2015 berada dalam sasaran target inflasi dan merupakan inflasi yang terendah dalam lima tahun terakhir. Konsistensi kebijakan moneter untuk menjaga stabilitas makroekonomi yang disertai koordinasi dengan Pemerintah berhasil mengendalikan inflasi 2015. Perkembangan inflasi yang kondusif pada awal tahun 2015 memberikan ruang bagi Bank Indonesia untuk menurunkan BI Rate pada Februari 2015. Namun demikian, Indeks Harga Saham 
Gabungan (IHSG) tahun 2015 mengalami koreksi atau berada dalam tren menurun.

Penguatan nilai tukar rupiah pada 2016 terutama terlihat pada tiga triwulan pertama 2016 dan sebelumnya kemudian melemah pada triwulan terakhir 2016. Selain itu, Inflasi Indeks Harga Konsumen (IHK) pada 2016 tercatat cukup rendah dan berada dalam rentang sasaran inflasi. Ruang pelonggaran kebijakan moneter pada periode tersebut cukup besar bagi Bank Indonesia untuk menurunkan suku bunga kebijakan dengan mempertimbangkan berbagai aspek stabilitas ekonomi yang tetap terjaga. Seiring dengan pertumbuhan ekonomi yang positif di tahun 2016, BEI berhasil mencatat kinerja positif, ditandai oleh pencapaian yang melampaui sasaran di hampir seluruh indikator pertumbuhan Bursa.

Dinamika nilai tukar menunjukkan rupiah bergerak stabil hingga menjelang akhir triwulan III 2017 dan kemudian cenderung melemah pada periode selanjutnya hingga akhir 2017. Inflasi indeks harga konsumen (IHK) 2017 tetap terkendali dalam rentang sasaran, didorong oleh perkembangan positif faktor domestik dan eksternal. Pada semester II 2017, Bank Indonesia memanfaatkan ruang pelonggaran yang tersedia dengan menurunkan suku bunga kebijakan pada bulan Agustus dan September 2017. Respons kebijakan ditempuh setelah mempertimbangkan ekspektasi inflasi yang menurun, defisit transaksi berjalan yang tetap berada pada tingkat yang aman, arah normalisasi kebijakan moneter Amerika Serikat yang lebih jelas, dan ketidakpastian ekonomi yang semakin menurun. Pada tahun ini juga Indeks Harga Saham Gabungan (IHGS) BEI terus mengalami peningkatan.

Ketidakpastian global yang tinggi dan memberikan tekanan kepada neraca pembayaran Indonesia (NPI) banyak memengaruhi dinamika nilai tukar rupiah pada 2018. Meski demikian, Inflasi tetap rendah terkendali dalam rentang sasaran. Inflasi yang rendah satu sisi dipengaruhi faktor siklikal dari global dan domestik. Bank Indonesia mulai menaikkan suku bunga kebijakan (BI7DRR) pada Mei 2018 merespons kenaikan FFR dan ketidakpastian pasar keuangan global yang mulai meningkat. Sejalan dengan tekanan ekonomi tersebut, IHSG terkoreksi hampir $2,6 \%$.

Secara parsial kurs memiliki pengaruh yang positif namun tidak signifikan terhadap IHSG. Pengaruh negatif menunjukkan adanya pengaruh yang searah antara inflasi dengan IHSG. Hal ini tidak jauh berbeda dengan penelitian yang dilakukan Kumalasari (2016) menunjukkan bahwa secara parsial variabel nilai tukar berpengaruh positif terhadap variabel Indeks Harga Saham Gabungan. Namun, hasil yang berbeda ditunjukkan dari penelitian yang dilakukan oleh Jayanti (2014) dimana nilai tukar Rupiah secara parsial mempunyai pengaruh negatif dan signifikan terhadap Indeks Harga Saham Gabungan.

Menurut Granger, et.al (1998) secara teoretis perbedaan arah hubungan antara kurs dan harga saham dapat dijelaskan dengan pendekatan tradisional dan model portofolio balance. Pendekatan tradisional mengatakan 
bahwa hubungan antara kurs dan harga saham adalah positif, di mana perubahan nilai tukar mempengaruhi kompetitifnya suatu perusahaan. Hal ini sebagai efek dari fluktuasi nilai tukar yang mempengaruhi pendapatan dan biaya operasional perusahaan, yang pada akhirnya menyebabkan perubahan pada harga sahamnya. Berlawanan dengan pendekatan tradisional, pendekatan "portofolio balance" mengasumsikan saham sebagai bagian dari kekayaan sehingga dapat mempengaruhi perilaku nilai tukar melalui hukum demand for money yang sesuai dengan model monetaris dari determinasi nilai tukar. Pendekatan ini mengasumsikan terdapat hubungan yang negatif antara harga saham dan nilai tukar, dengan arah kausalitas dari pasar saham ke pasar uang, sesuai dengan interaksi pasar keuangan yang sangat cepat.

Secara parsial inflasi berpengaruh secara negatif tidak sigifikan terhadap IHSG. Pengaruh negatif menunjukkan adanya pengaruh yang berlawanan antara inflasi dengan IHSG. Secara teori dapat dijelaskan bahwa tingkat inflasi yang tinggi biasanya dikaitkan dengan kondisi ekonomi yang terlalu panas (overheated). Artinya, kondisi ekonomi mengalami permintaan atas produk yang melebihi kapasitas penawaran produknya, sehingga harga-harga cenderung mengalami kenaikan (Untono 2015).

Hasil terebut sejalan dengan penelitian yang dilakukan oleh Wijayanti (2017) yang menyatakan bahwa dalam jangka pendek tingkat inflasi tidak berpengaruh signifikan terhadap IHSG. Pengaruh yang tidak signifikan menandakan bahwa tingkat inflasi tidak berpengaruh banyak terhadap keputusan investor dalam menanamkan modalnya. Jika dilihat berdasarkan parah tidaknya, inflasi yang terjadi selama periode penelitian digolongkan dalam inflasi ringan (dibawah $10 \%$ pertahun), sehingga para investor menganggap inflasi yang terjadi hanya sementara dan akan segera pulih serta beranggapan bahwa menjual saham saat inflasi naik akan sia-sia dan hanya menambah kerugian.

Secara parsial BI rate berpengaruh secara negatif dan signifikan terhadap IHSG. Pengaruh negatif menunjukkan adanya pengaruh yang berlawanan antara perubahan inflasi dengan IHSG. Hal ini disebabkan pada saat tingkat bunga sedang tinggi, para investor lebih cenderung menginvestasikan dananya di bank dibandingkan di pasar modal. Dalam keadaan ceteris paribus jika tingkat bunga sedang tinggi maka investasi di pasar modal akan turun, terutama bagi investor dengan tipe konservatif (risk averse) yang lebih memilih investasi dengan resiko rendah.

Hasil penelitian ini sejalan dengan penelitian yang dilakukan Kumalasari (2016) dan didukung pula oleh penelitian yang dilakukan Taufiq dan Kefi (2015) dimana BI rate berpengaruh negatif dan signifikan terhadap IHSG. Tingkat bunga yang tinggi merupakan sinyal negatif terhadap harga saham. Tingkat suku bunga yang meningkat menyebabkan investor menarik investasinya pada saham dan memindahkannya pada investasi berupa tabungan ataupun deposito 
(Kewal, 2012). Weston dan Brigham (1994) mengemukakan bahwa tingkat bunga mempunyai pengaruh yang besar terhadap harga saham. Suku bunga yang makin tinggi memperlesu perekonomian, menaikkan biaya bunga dengan demikian menurunkan laba perusahaan, dan menyebabkan para investor menjual saham dan mentransfer dana ke pasar obligasi.

\section{Daftar Pustaka}

BI. 2003. Bank Indonesia Bank Sentral Republik Indonesia: Tinjauan Kelembagaan, Kebijakan, Dan Organisasi. Jakarta: Pusat Pendidikan dan Studi Kebanksentralan (PPSK).

Granger C. W., Huang B. and Yang C. 1998. A Bivariate Causality Between Stock Prices And Exchange Rates: Evidence from Recent Asian Flu. The Quarterly Review Of Economics And Finance. Volume 40:337-354

Husnan, Suad. 2002. Dasar-dasar Manajemen Keuangan Internasional. Yogyakarta: Penerbit Andi.

Jayanti, Yusnita. 2014. Pengaruh Tingkat Inflasi, Tingkat Suku Bunga SBI, Nilai Tukar Rupiah, Indeks Dow Jones, dan Indeks KLSE terhadap Indeks Harga Saham Gabungan (IHSG) Studi Pada Bursa Efek Indonesia Periode Januari 2010 - Desember 2013. Jurnal Administrasi Bisnis (JAB) 11(1): 1-10.

Kewal, Suramaya. 2012. Pengaruh Inflasi, Suku Bunga, Kurs, dan Pertumbuhan PDB Terhadap Indeks Harga Saham Gabungan (IHSG). Jurnal Economia 8(1): 53-64.

Martalena dan Maya Malinda. 2011. Pengantar Pasar Modal. Yogyakarta: Penerbit Andi.

Untono, Michael. 2015. Analisis Pengaruh Pertumbuhan Ekonomi, Inflasi, Nilai Tukar, Indeks DJIA, Dan Harga Minyak
Dunia Terhadap Indeks Harga Saham Gabungan. Parsimonia 2(2): 1-12.

Sugiyono. 2014. Metode Penelitian Bisnis. Bandung: Penerbit Alfabeta.

Sunardi, N. dan Ula, L.N.R. 2017. Pengaruh BI Rate, Inflasi Dan Kurs Terhadap Indeks Harga Saham Gabungan (IHSG). Jurnal Sekuritas: Saham, Ekonomi, Keuangan dan Investasi 1(2): 27 - 41.

Taufiq, M. dan Kefi, B.S. 2015. Pengaruh Inflasi, BI Rate Dan Kurs Terhadap Indeks Harga Saham Gabungan. Jurnal Ekonomi Manajemen Akuntansi 22(38): $1-14$.

Wijayanti, Ikka. 2017. Analisis Pengaruh Tingkat Inflasi, BI Rate, Kurs, Dan Standard \& Poor's 500 Terhadap Indeks Harga Saham Gabungan (IHSG) Di Bursa Efek Indonesia (BEI) Tahun 2014-2016. Jurnal Ilmiah Fakultas Ekonomi dan Bisnis Universitas Muhammadiyah Surakarta. 